\title{
Antik Dönem Ege Uygarlıkları Seramiklerinde Homeros’un İlyada Destanından Seçilmiş Sahne Tasvirleri
}

\author{
Descriptions of the Selected Scenes of Homer's Iliad in Ancient Aegean \\ Civilizations Ceramics
}

\section{Sevinç Köseoğlu Ulubatlı}

Araştırma Görevlisi, Ankara Hacı Bayram Veli Üniversitesi Sanat ve Tasarım Fakültesi Seramik Tasarımı Bölümü email: sevinc.koseoglu@hbv.edu.tr (DORCID ID: https://orcid.org/0000-0003-1369-2395

\author{
iThenticate' Bu makale bilimsel etik ve kurallara uygun hazırlanmış ve intihal incelemesinden geçirilmiştir. \\ Atıf (APA 6)/To cite this article \\ Köseoğlu Ulubatlı, S. (2020). Antik dönem Ege uygarlıkları seramiklerinde Homeros'un İlyada destanından seçilmiș sahne tasvirleri. Atatürk \\ Üniversitesi Güzel Sanatlar Enstitüsü Dergisi, 26(44), 61-72. doi: https://doi.org/10.35247/ataunigsed.669556
}

Makale Gönderim Tarihi/Received: 02/01/2020

Makale Kabul Tarihi/Accepted: 12/03/2020

Makale Yayın Tarihi/Published: 19/03/2020

Review Article / Derleme Makalesi

\section{$\ddot{\mathbf{O z}}$}

Homeros'un İlyada Destanında anlatılan olaylar ve kahramanlar, antik dönem sanatına ve özellikle orta çağdan itibaren de resim sanatına ilham kaynağı olmuș ve İlyada'dan alınan temalar yoğun bir şekilde seramik kaplar, heykeller, duvar resimleri, metal eşyalar, taş kabartmalar ve ahşap paneller gibi sanat eserlerinde kullanılmıștır. Özellikle M.Ö. 6. Yüzyıldan M.Ö. 3. Yüzyıla kadar üretilen Antik Ege Uygarlıkları seramik çömlek ve kaplarda siyah ve kırmızı figürlü boyama tekniği ile resmedilmis Troya savaşının kahramanları ve maceraları dikkati çekmektedir. Seramik sanatçıları ilk önce siyah figürlü teknikle açık renkli (sarıkahverengi tonları) zemine koyu renkli figürler ișlemișlerdir. Kırmızı figürlü teknikte ise koyu renk zemin üzerinde açık renkli karakterler yer almış ve bu şekilde tasvir edilen olay ve karakterler daha net ortaya çıkmaktadır.

$\mathrm{Bu}$ çalışma kapsamında, Troya Savaşı'nın en destansı sahnelerinin konu edildiği antik döneme ait siyah ve kırmızı figürlü seramik eserleri, İlyada metininden anlatıya karşılık gelen alıntılar eşliğinde ya da mitolojik hikayeler anımsatılarak ele alınacaktır. Seramik üzerinde bulunan sahnelerin ikonografik çözümlemeleri yapılacak ve seramik eserin üretilme tekniği hakkında bilgiler verilecektir.

Anahtar kelimeler: Homeros, Troya, Seramik, Antik Dönem, Kırmızı Figürlü, Siyah Figürlü

\begin{abstract}
The events and heroes described in Homer's Epic of Iliad have inspired the art of antiquity and especially the art of painting from the middle ages. Themes taken from the Iliad have been used extensively in works of art such as ceramic pots, sculptures, mural paintings, metal items, stone reliefs and wooden panels. Especially starting from 6th century BC and lasting until the 3rd century BC, the heroes and adventures of the Trojan War, which were painted on the ancient Greek pottery and vessels, created with the black and red figure painting technique, are among the prominent art objects. Ancient ceramic artists first placed darkcolored figures on the lightly colored (yellow-brown tones) background, which is called as "black figure technique." In the red-figure technique, lightly colored characters were placed on a dark background and the events and characters depicted in this way were revealed more clearly.

Within the scope of this study, the ancient ceramic works of black and red figurines from the ancient period, where the most epic scenes of the Trojan War are depicted, will be narrated with quotations from the original text of the Iliad or with corresponding mythological stories. Iconographic analysis of the scenes on ceramic objects will be made and information about the production technique of ceramic works will be evaluated
\end{abstract}

Keywords: Homer, Troy, Ceramics, Ancient Period, Red Figured, Black Figured

\section{Giriş}

Çanakkale il sınırlarında bulunan Troya Tarihi Milli Parkı, sadece Türkiye'nin değil, aynı zamanda tüm dünyanın da en önemli arkeolojik alanlarından birisidir. Homeros'un destanlarına konu olan Troya/Hisarlık Tepe yerleşim alanı Çanakkale Boğazı'nın Asya kıyılarında yer alır. Ege ve Karadeniz, Asya ve Avrupa arasındaki avantajlı konumu, bölgenin üç bin yıl boyunca sürekli yerleşim görmesini sağlamıştır. Troya, kimi zaman Akdeniz ticaretinin önemli bir kilit noktası olmuş, kimi zaman depremlerle yıkılıp harap olmuş, kimi zaman da savaşlarla yakılıp yıkılmıştır.

17. yüzyılda, yabancı uyruklu arkeologlar Homeros'un Troya'sının konumunu tespit etmek üzere ilk çalıșmalarını yapmışlardır. Frank Calvert (1863-1865) ile 1863 yılında başlayan kazılar, sırasıyla Henrich Schliemann (18701890), William Dörpfeld (1893-1894), C. W. Blegen (1932-1938), M. O. Korfmann (1988-2005) ile devam ettirilmiştir. Günümüzde de kazılar Prof. Dr. Rüstem Aslan başkanlığında sürdürülmektedir ("Kültür Varlıkları ve Müzeler Genel Müdürlüğü”, t.y.)

Troya Antik Kenti, 1998 yılında, UNESCO tarafından "Dünya Mirası” olarak kabul edilmiş, yani uluslararası önem taşıyan, bütün insanlığın ortak mirası olarak kabul edilen ve bu nedenle tanıtıma ve korunmaya değer doğal oluşumlar, anıtlar ve sitler arasında yer almıştır. UNESCO Dünya Miras Listesi'nde yer alan 17 miras 
varlığımızdan birisi olan Troya Antik Kenti'nin bu listeye girmesinin 20. Yıl dönümü olan 2018 yılı Türkiye'de "Uluslararası Troya Yılı" ilan edilmiştir ("Kültür Varlıkları ve Müzeler Genel Müdürlüğü", t.y.).

Homeros'un İlyada Destanı, Troya olarak anılan kentin destanıdır. Her ne kadar konusu Troya savaşı olsa da bilinen tarihin ilk dünya savaşı niteliğindeki bu savaşın öncesi ve sonrasının büyük hikayesini ve masal çemberinin bütününü anlatmaz bize. İlyada'da bütün bir savaşın öncesi ve sonrasıyla bir otuz yıll süreyle uzanan öyküsünü arayan okuyucu büyük bir düş kırıklığına uğrar. Aslında İlyada Troya'nın destanı değil, Akhilleus'un destanı sayılmalıdır (Homeros, 2002, s. 29).

Homeros, İlyada Destanı'nda konuyu sınırlamıştır. Akhilleus'un Akha ordularının kralı Agamemnon'a karşı öfkesi ve ona isyan edip savaşmayı bırakması ile başlar destan. Ancak daha sonra en yakın arkadaşı Patroklos'un Hektor tarafindan öldürülmesi üzerine savaşa intikam almak için geri döner ve Troyalıların baş kahramanı Hektor ile çarpışarak onu öldürür. Hektor'un ölü bedenini arabasına bağlar ve onu Troya surlarının etrafında acımasızca yerlerde sürüklemesini herkese izletir. Hektor'un babası Troya Kralı Priamos'un isteği üzerine insafa gelir ve Hector'un işkence görmüş bedenini babasına vermeyi kabul eder. İlyada burada biter ama Troya savaşının destanı İlyada ile ne başlar ne de biter (Homeros, 2002, s. 30).

\section{Yöntem}

Araştırma betimsel modele dayalı olarak yürütülen nitel bir araştırma olup derleme niteliğindedir. Araştırma kapsamında konu ile ilgili literatür taraması yapılarak veriler toplanmıştır. Derlenen veriler ışığında antik dönem Ege uygarlıkları seramiklerinde konu olarak işlenen Homeros'un İlyada Destanından seçilen sahneler incelenmiş̧ir.

\section{Bulgular}

\subsection{Antik dönemde ritüel/kült kapları ve hikaye anlatıcılı̆̆ı}

M.Ö 6. ila M.Ö. 3. yüzyıllar arası antik Yunan seramik eserleri günlük kullanımdan dini ayinlere ve ölü gömme geleneklerine kadar hayatın farklı aşamalarında kullanılmıştır. Katı ve sıvı nesneler için tasarlanan bu kaplar kullanım amaçlarına göre boyutu, genişliği ve derinliği farklı özellikler göstermektedir. Doğum, evlilik ve ölüm gibi önemli anlarda gerçekleştirilen dini seremonilerde kullanıldığı düşünülen ritüel ve kült kaplarında gerek form biçimi olarak gerekse süsleme ve tasvir karakteri olarak zengin üsluplar sergilendiği görülmektedir (bkz. Görsel 1).

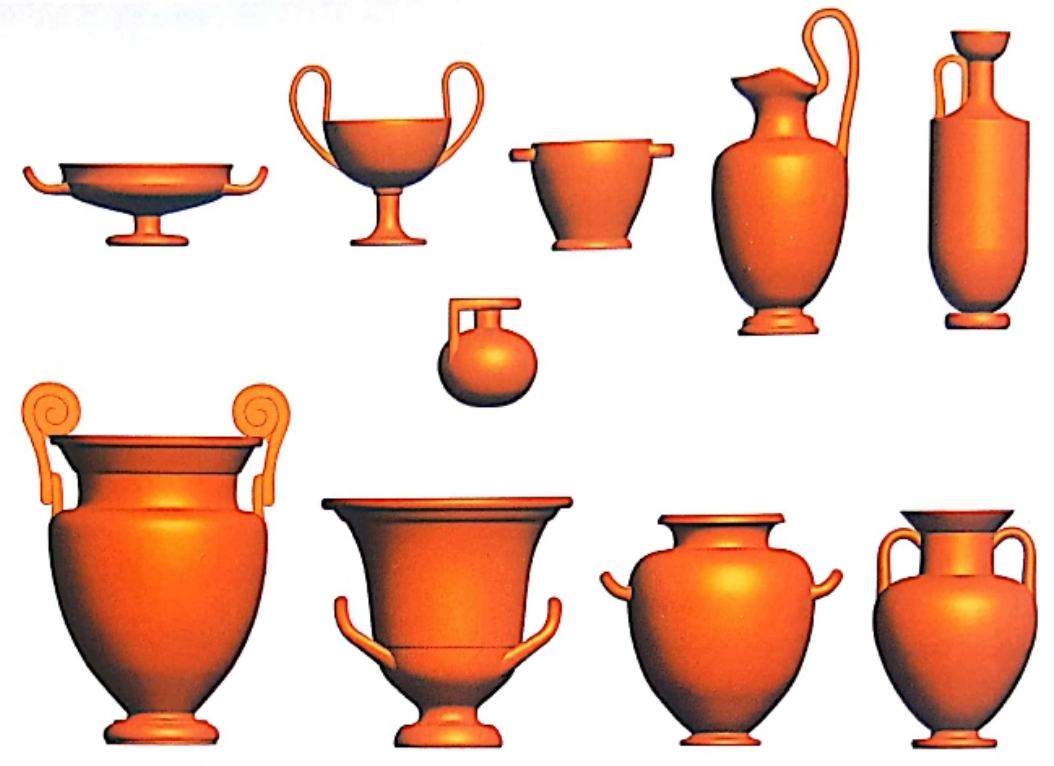

Görsel 1. Antik Dönem Yunan kaplarının tipolojisi

Özellikle ölüm ayinlerinde sunu, adak ve kurban kültü ritüel kaplarının önemini ortaya koymaktadır. Ölülere sunulan katı ve sıvı sunuların ritüel kapları içine konulduğu bilinmektedir. Homeros, Patroklos'un cenaze töreninde Akhilleus tarafindan 12 Troyalı genç, 4 at, 2 köpek, sığır ve dişi koyunlar kurban edildiğini, yağların ve kanların kaplar içerisinde sunulduğunu aktarmaktadır (Homeros, 2002, XVI. Bölüm, Dize: 160-180). Homeros bir başka destanı olan Odysseia'da, Odysseus'un ölüler ülkesinde ölülere kurbanların kanı ile sunu yaptığını ve ruhların bu kanları içmek için geldiklerini anlatmaktadır (Homeros, 2001, XI. Bölüm, Dize: 20-50). 


\subsection{Antik dönemde seramiklerin renklendirilmesi: siyah ve kırmızı figürlü boyama tekniği}

Antik Dönem "Yunan ve Roma Sanatları ile bu dönemden kalan sanat ve mimarlık yapılarını nitelemede sıkça kullanılan bir terim" olarak nitelendirilmiştir (Yoleri, 2008, s. 62). M.Ö 7. ila M.Ö. 3. yüzyıllar arasında "nüfus artışı ile Anadolu'dan Kuzey Afrika ve İspanya'ya kadar yayılan küçük koloniler, Akdeniz, Ege ve Karadeniz kıyılarına kadar yayılmış, Mısır, Suriye, Mezopotamya ve Hindistan'ın da etkisi ile seramik sanatı büyük bir kültürel zenginliğe ulaşmıştır. Bu dönemde dekorlu seramiklerin üretildiği önemli ticaret merkezlerinden biri haline gelen Korinth ve pek çok kaynakta karşımıza "Attik” olarak çıkan Atina'dır" (Yoleri, 2008, s. 62). Bu ticaret yolu sayesinde ortaya çıkan kültürler arası etkileşimi Önal ve Uludağ (2019), şöyle açıklamaktadır; "bölgelere ve kültürlere ait farklı ticaret ve göç yollarının, önemli merkezlerin, devletlerin ya da kavimlerin ortaya çıkması ile o bölgelerin diğer bölgelere etkilerinin de gözlemlenmesi söz konusu olabilmiş böylece kültürler arası etkileşimlerde ortaya çıkarılmıştır" (s. 27).

Akdeniz ticaret pazarının aranan ürünleri haline gelen dekorlu seramiklerin su geçirgenliği ve dayanıklılığını artırmak için sadece perdah değil pekişmiş astarlarda kullanılarak astar üzerine dekorlama yapılmıştır. Bu astar, terra sigillata astarı denilen çok ince tanecikli ve demir bileşenleri ile zengin killerden hazırlanan bir astar çeşidi olup "pişirim sürecinde, fırın atmosferine bağlı olarak kırmızıdan siyaha değişen tonlarda renkler oluşturabilir" (Aslan ve Canduran, 2016, s. 54). Çizer (2014)'e göre, “Antik çağda, Ege ve Akdeniz uygarlıklarında kullanılmakta olan firınlar, doğal olarak odun yakıtlı olduğundan indirgen pişirim ortamı oluştuğunda, terra sigillata astarını siyah renkte pişirmek hem kolay hem de kaçınılmazken, kırmızı renkli ürün elde etmek ise tamamen rastlantiya kaliyordu" (aktaran Aslan ve Canduran, 2016, s. 52).

Antik dönem çömlekçilerinin seramik kaplardaki kaplama ve bezeme yöntemlerini kullanması bin yıllar boyu süren bir çaba ve deneyimin, kuşaktan kuşağa aktarılarak biriktirilmesi ile mümkün olmuştur. Özellikle kırmızı ve siyah figürlü seramiklerin görüldüğü antik dönemdeki sanatçılar killerin pişme öncesi ve sonrası renk ve parlaklık özellikleri gibi malzeme kalitesine dair konularda deneyimlerini artırmayı başarmışlardır. Çizer (2014), kırmızı ve siyah figürlü seramiklerin üretildiği dönemi antik seramiğin altın çağı olarak adlandırmıştır. Ona göre en mükemmel parlaklığa M.Ö. 5. Yüzyılda Klasik Dönem Attika kaplarında ulaşılmıştır (s. 26-27).

M.Ö 7. ila M.Ö. 3. yüzyıllar arası antik Yunan seramik eserleri iki türlü boyama tekniği ile işlenmiştir. İlk olarak Korinth'te ortaya çıkan ve sonrasında Anadolu coğrafyasında da yayılan siyah figürlü teknik M.Ö. 6. yüzyıla kadar kullanılmıştır. Siyah figürlü teknikte kırmızı zemin üzerine (sarı ile kahverengi tonları arası) siyah karakterler ya da imgeler işlenmiştir. Dekorlama işlemine başlarken kabın tüm yüzeyine firça yardımıyla ince bir katman doğal demir oksit uygulanmıştır. Bu katman pişirim sonrası kırmızı renge dönüşerek kompozisyonun zeminini oluşturmuştur. Parça üzerine konturlanarak figürler resmedilmiş ve astar ile figürlerin içi doldurulmuştur. Silüet halinde boyanmış figürlerdeki saç, sakal, elbise kıvrımları gibi detaylar sivri uçlu bir alet ile alttaki gövde rengi ortaya çıkacak şekilde kazınmıştır. Bu şekilde açık renk fon üzerine oyma tekniğiyle belirginleştirilmiş koyu renkli figürlerin olduğu kompozisyonlar ortaya çıkmıştır (Dphil, 2011, s. 1; Çizer, 2014, s. 90).

Kırmızı figürlü teknik, siyah figürlü tekniğin tersi olarak uygulanmış bir yöntemdir. M.Ö. 6. yüzyılda ilk Atina'da ortaya çıkan bu teknikte, siyah zemin üzerine kırmızı figürler (sarı ile kahverengi tonları arası) ve imgeler yer alır. Figürler parça üzerine çizildikten sonra içleri boş bırakılır ve çevreleri astar malzemesi ile boyanır. Kırmızı figürlü teknikte karakterlerin hatları daha belirgin ve kompozisyon daha net şekilde bezenmiştir (Dphil, 2011, s. 1; Çizer, 2014, s. 91).

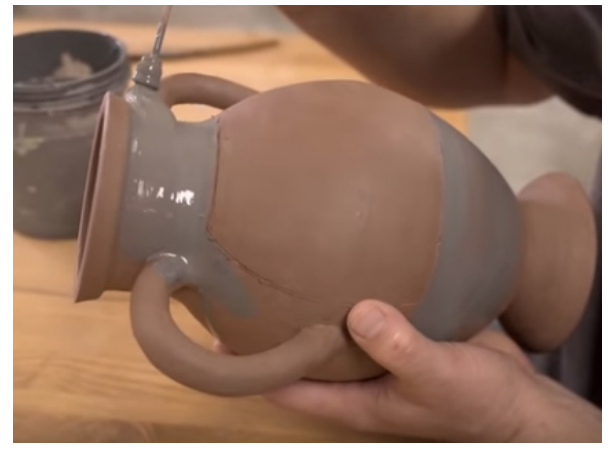

Görsel 2. Seramik formun astarlanmas1

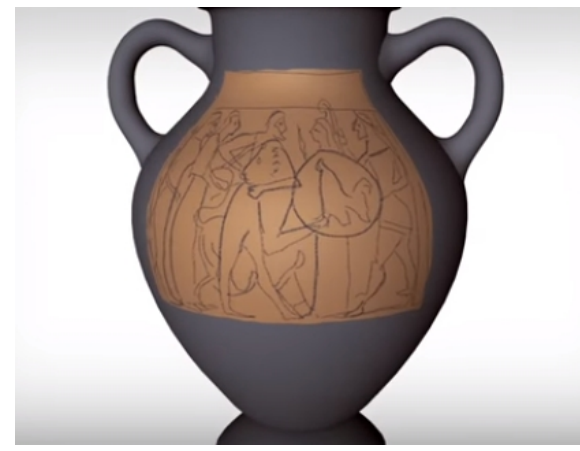

Görsel 3. Astarlanmıș seramik formun üzerine çizimin yapılması

Antik dönemin seramik sanatçılarının, elleri ile şekil verdikleri seramik kaplarda ahşap ve metalden yapılmış el aletleri kullandıkları düşünülmektedir. $\mathrm{Bu}$ aletler sayesinde çamura istedikleri şekli verebilmiş ve yüzeyleri pürüzsüz hale getirmişlerdir. İlk olarak gövdesini oluşturdukları kaplara, sonradan kaidesini ve kulplarını 
eklemişlerdir. Tasarımı biten kaplarda renklendirilecek alanın çevresi konturlanarak belirlenmiştir. Sanatçılar, siyah ve kırmızı figürleri elde edebilmek için çamur kıvamında sıvı kil (astar) kullanmışlardır (bkz. Görsel 2). Tasvir eklenecek alan taslak çizimlerle hazırlanır (bkz. Görsel 3) ve sonrasında astar yardımıyla içleri doldurulur (bkz. Görsel 4). Günümüze kadar gelen antik dönem figürlü vazolar özel firınlarda (bkz. Görsel 5) farklı derecelerde üç aşamalı pişirme sürecinden geçirilerek üretilmiştir.

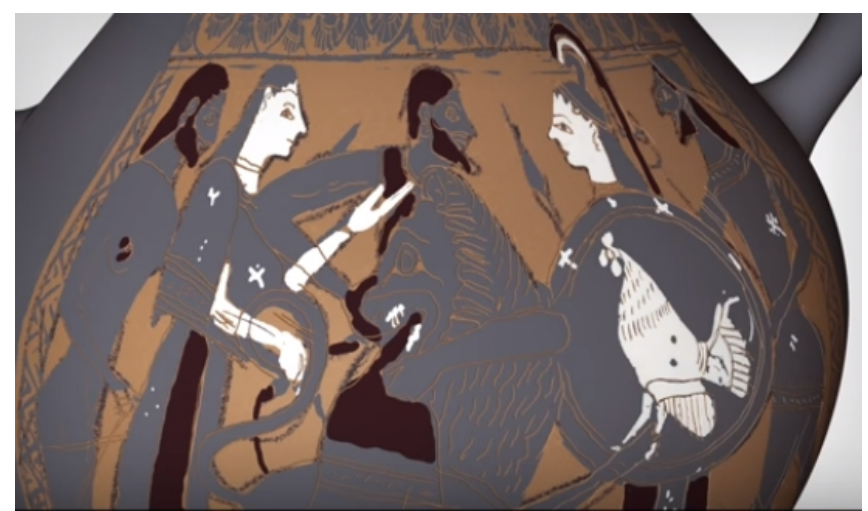

Görsel 4. Çizimlerin içlerinin astarlanması

Antik Ege seramikleri üzerinde yer alan bezemeler, seramik üretim aşamasında kullanılan malzeme alet ve üretim tekniği hakkında önemli veriler sağlamaktadır. Tasvirlerde pergel, kompas gibi aletlerin kullanımı ile hem dengeli çizimler yapmak hem de tekerlek ve kalkan gibi oval figürleri çizmek için kullanıldığı anlaşılmakta olup boyama işleminde de farklı kalınlık ve genişlikte firçaların kullanıldığı görülmektedir. Çizer, "betimlemelere dayanarak dekorlama işleminin birden fazla sanatçı tarafından bir iş birliği içinde gerçekleşmiş olabileceğini aktarmaktadır. Bu durumda, desen çiziminin, dolguların, ayrıntılı çizimlerin ve firınlamanın farklı sanatçılar tarafından yapıldığı düşünülmektedir" (Çizer, 2014, s. 90).

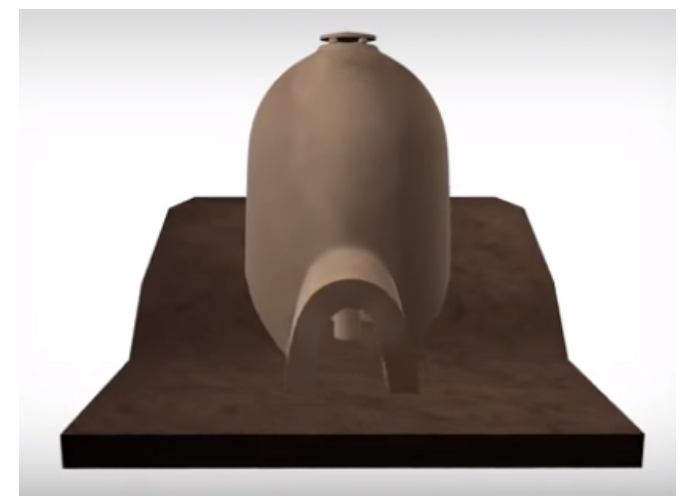

Görsel 5. Seramiklerin pişirildiği firın

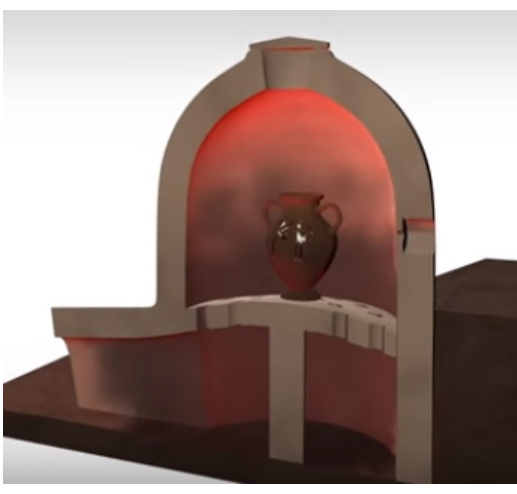

Görsel 6. Pişirim esnasından bir görünüm

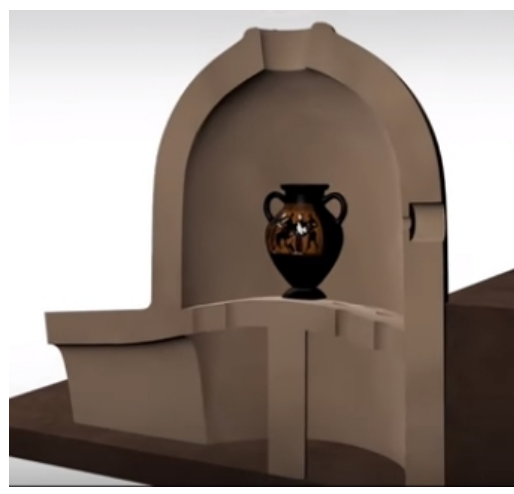

Görsel 7. Pişirim sonrasında bir görünüm

Fırınlanmaya hazır hale gelen seramik kaplar özel fırınların içine yerleştirilir ve ilk aşama olan 800 derecede pişirilir ve sonra ortama hava verilerek oksitlenme sağlanmaktadır. İlk aşamada seramik kabın gövdesi kırmızıya dönüşmektedir (bkz. Görsel 6). İkinci aşamada havalandırma kanalı kapatılır ve fırın içi sıcaklığı tekrar artırılarak 950 dereceye kadar yükseltilmektedir. Bu aşama sonunda kabın yüzeyi siyaha dönüşürken, astar ile boyanan tasvir 
alanı parlaklaşır ve cam gibi bir görüntü halini almaktadır. Son aşamada havalandırma kanalları yeniden açılır ve firın haznesinde oksijen salınımı sayesinde oksitlenme sağlanır, cam gibi parlayan figürler siyahlaşır ve figürlerin arka planı kırmızıya (sarıdan kahverengiye çalan tonlar arasında) dönmektedir (bkz. Görsel 7) ("Khan Academy”, t.y.).

\subsection{Troya Savaşı öncesi, sonrası ve seramik örneklerde tasvirleri}

Homeros'un destanları ve özellikle Troya Savaşı'nın unutulmaz sahneleri antik dönem sanatından itibaren dünya sanatını büyük ölçüde etkilemiştir. İlyada Destanının her sahnesi etraflıca burada anlatılmaya değer ancak önceliğimiz genelde okuyucuda, edebiyat ve sanatta daha fazla iz bırakmış olan sahnelere odaklanmak olacaktır. Özetle, bu sahneler:

- Akhilleus ve Agamemnon arasındaki tartışma ve Akhilleus'un kızgınlığı ve savaştan çekilmesi

- Paris'in Menelaus'a meydan okuması ve teke tek dövüşmesi

- Akha kahramanı Diomedes'in Aineias ile savaşı

- Hektor ile Aias arasındaki günlerce süren ancak yenişemedikleri savaş

- Hektor ile Patroklus'un savaşı ve Patroklus'un ölmesi

- Akhilleus'un intikam için savaşa geri dönmesi ve Hephaistos'un ona yeni silahlar yapması

- Akhilleus ile Hektor'un çarpışması ve Hektor'un trajik ölümü

- Kral Priamos'un oğlu Hektor'un ölüsünü almak için Akhilleus'a gidip yalvarması.

\subsubsection{Paris'in kararı}

Antik dönem için bir dünya savaşı niteliğinde olan Troya savaşı, aslında Nifak ve Kavga Tanrıçası olan Eris’in sebep olduğu bir kargaşadan kaynaklanmaktadır. Bu anlatıyı kısaca anımsayacak olursak:

“...En büyük ve en güçlü tanrı olan Zeus günün birinde güzeller güzeli deniz tanrıçası Thetis ile buluşur. Zeus, deniz tanrıçasını öylesine beğenir ki, ondan bir çocuğu olmasını ister. Ama bu mümkün değildir çünkü geleceği görebilen biliciler deniz tanrıçası Thetis'e çocuğunun babasını alt edeceğini söylerler. Gücünü kaybetmekten korkan Zeus bu işten vazgeçer, çünkü kendisi de babasını devirip onun yerine geçmiştir. Bu nedenler güzel Thetis'i ölümlü bir erkekle evlendirmek ister. Aday olarak da Peleus'u seçer. Thetis bu evliliğe karşı çıkar. Ölümsüz bir tanrıça olarak, ölümlü bir erkeği kocası olarak kabul etmez; ancak herşeye rağmen Zeus'un isteğine boyun eğmek zorunda kalır. Tanrıça Thetis kız kardeşleriyle denizden çıkıp dolunayda dans etmek isterken, Peleus'un eline esir düşer. Peleus'un elinden sürekli başka kılıklara girerek kurtulmak ister; kıvrıla kıvrıla giden yılan olur, alev alev ateş olur, kükreyen aslan olur, ama yine de kurtulamaz Peleus'un elinden. Sonunda diğer tanrılar da bu evliliği kabul ederler ve Peleus ile Thetis evlenir. Düğüne tanrılar ve insanlar davet edilir ama o düğün telaşında sadece Kavga ve Nifak Tanrıçası Eris unutulur. Buna çok sinirlenir Eris, intikam almak için yemin eder. Dügüunün en güzel anında orta yere üzerinde "en güzeline" yazılı altın bir elma atar. Zeus'un daha önce planladığı gibi üç tanrıça altın elmaya sahip olmak için birbirleriyle kavga etmeye başlar" (Aslan, 2018, s. 7-8).

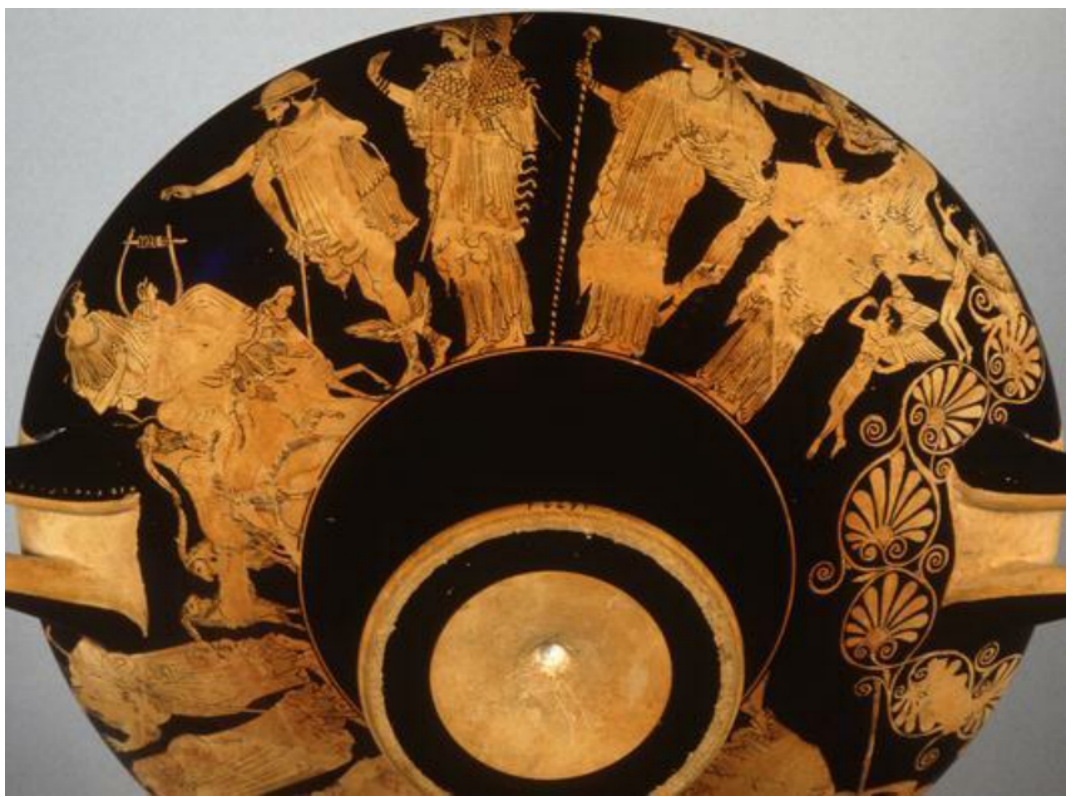

Görsel 8. Paris’in Kararı. (M.Ö. 7.yy.). Staatliche Museen zu Berlin’de Bir Vazo 
Bu düğünde yaşanan olaylar ileride Troya Savaşı'na yol açacak gelişmelerin de kıvılcımı olur çünkü Zeus; Hera, Athena ve Afrodit arasındaki güzellik yarışında hakem olarak Troya Kralı Priamos'un oğlu Paris'i görevlendirecektir. Dünyanın bilinen ilk güzellik yarışmasında Paris, kendisine dünyadaki en güzel ölümıü kadını rüşvet olarak teklif eden Afrodit'i en güzel tanrıça seçecek ve altın elma da onun olacaktır. Paris'e sunulan en güzel kadın, Sparta Kralı Menelaus'un karısı Spartalı Helen'dir. Helen evli bir kadın olmasına rağmen, Paris bu duruma aldırmaz ve ona vaad edilen Helen’i Troya'ya kaçırır. Bunun üzerine, Agamemnon'un desteğini alan ve intikam yemini eden Menalaus ve diğer Akha kralları, 30 yıl sürecek olan Troya Savaşı'nı başlatacak ve savaşlar ve ölümlerle dolu uzun bir dönem başlamış olacaktır (Graves, 2012, s. 831-834).

$\mathrm{Bu}$ önemli sahne çeşitli dönemlerde sanatta ele alınmıştır ve pek çok kez tasvir edilmiştir. "Paris'in Kararı" teması MÖ 7. Yüzyıldan itibaren antik seramik eserlerde görülmektedir. Staatliche Museen zu Berlin'de sergilenen seramik bir kapta (bkz. Görsel 8) Paris, Hermes, Eros, Hera, Afrodit ve Athena beraber resmedilmiş ve "Paris'in Kararı" konusu işlenmiştir. Kırmızı figür tekniği ile yapılan bu tasvirde siyah zemin üzerinde karakterler açık renkle resmedilmiştir. Paris, solda oturur vaziyette, elinde lir ve etrafında hayvanlarla tasvir edilmiştir. Onun yanında kanatlı ayakkabıları ile Hermes; üç güzel adaydan Athena zırh içinde ve mızrağıyla; Hera başında tacı ve elinde asasıyla, Afrodit ise yanından hiç ayrılmayan yoldaşı Eros ile birlikte resmedilmiştir.

"Paris'in Kararı" konusunun işlendiği diğer bir örnek M.Ö 6. yüzyıla ait siyah figürlü bir seramik amforadır (bkz. Görsel 9). Açık renk zemin üserine koyu renklerle resmedilen Paris ve Hermes’ in son kararı vermek için tartıştığı anın tasvir edildiği kompozisyona Hera, Afrodit ve Athena eşlik etmektedir.

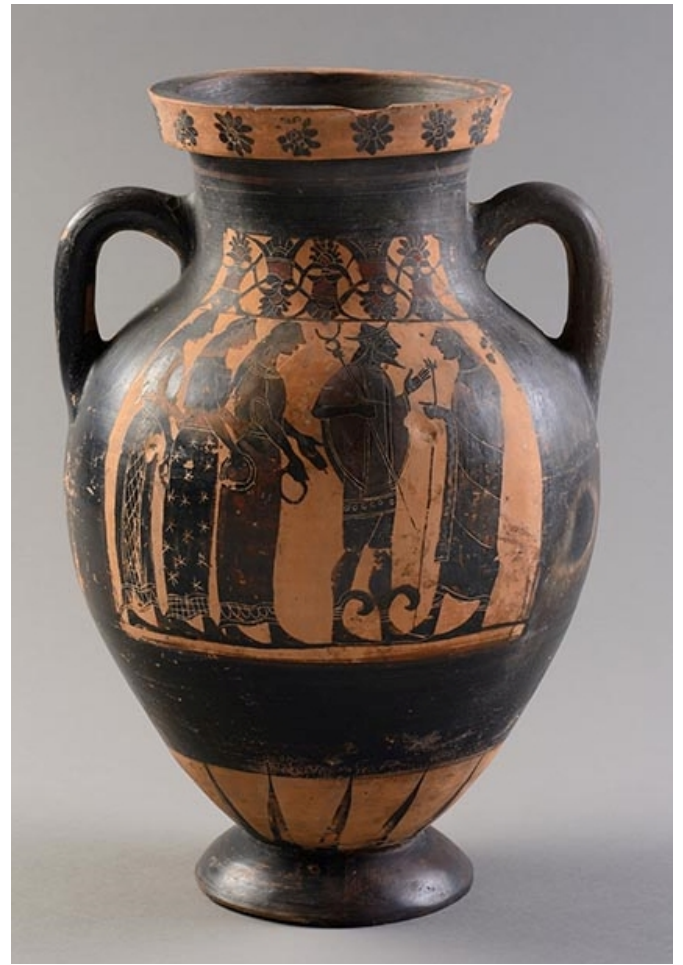

Görsel 9. Paris’in Kararı. (MÖ 6. yy.). Siyah Figürlü Boyama Tekniği. Lyon Güzel Sanatlar Müzesi

\subsubsection{Patroklus'un ölümü}

Tanrıların da isteği ve yönlendirmeleriyle artık büyük savaş başlamıştır. Akhalar gemileriyle Ege Denizi'ni aşmışlar ve Troya kıyılarına gelmişlerdir. Bir tarafta Akhilleus, Agamemnon, Menalaus, Odysseus, Aias, Patroklus ve Diomedes; diğer tarafta ise Hektor, Paris, Priamus ve Aineias vardır.

Kibirli Akhilleus ile Agamemnon'un arası savaşın daha başında köle Briseis yüzünden açılmıştır. Akhilleus'un savaş ganimeti olan Briseis’i Agamemnon kendisine almıştır. Buna öfkelenen Akhilleus sadece Agamemnon'a kızmakla kalmaz, aynı zamanda savaştan da çekilir. Bu durum Akhaları çok etkileyerek ve Hektor'un da kahramanca çarpışmasıyla savaşta geriye düşmelerine neden olacaktır.

Akhaların bu durumuna daha fazla dayanamayan Akhilleus'un yakın arkadaşı Patroklos'un, Akhilleus'un zırh ve kalkanını kuşanarak Hektor ile savaşmaya gittiği ifade edilmektedir. Üstesinden gelemeyeceği bir göreve kalkışan Patroklus, ilk başlarda başarılı olsa da, Hektor tarafından öldürülür. Bu ölüm, savaşın kaderini etkileyecek kadar önemlidir. En yakın dostu Patroklos'un öldüğü haberini alan Akhilleus intikamını almak için yeniden savaşmaya karar verir. Hektor ile Patroklus çarpışmasını Homeros, XVI. Bölüm, Dize: 818-823'de şu dizelerle anlatmaktadır: 
"Hektor ulu canlı Patroklus'u gördü,

Sivri kargıyla yaralanıp geri çekilirken,

Sıraları aşıp yaklaştı ona, sapladı kargısını,

Sapladı karnının altına, soktu tuncu dibine kadar,

Patroklos gürültüyle yere yıkıld1,

Büyük bir yas girdi Akha ordusuna" (Homeros, 2002, s. 382).

$\mathrm{Bu}$ trajik sahne de antik dönem seramiklerinde birçok kez resmedilen sahnelerden birisidir. Siyah figürlü Antik Yunan vazosunda Akhilleus, Patroklus'un yerde yatan cesedini savaş alanından almak için mücadele vermektedir (bkz: Görsel 10). Açık renk zemin üzerinde siyah silüetleri ile zırhları ve miğferleriyle resmedilen askerler amansızca çarpışmaktadırlar. Siyah figürlerin üzerindeki konturlarla karakterlerin kıyafetlerinin ve vücut hatlarının detaylarına yer verilmiştir.

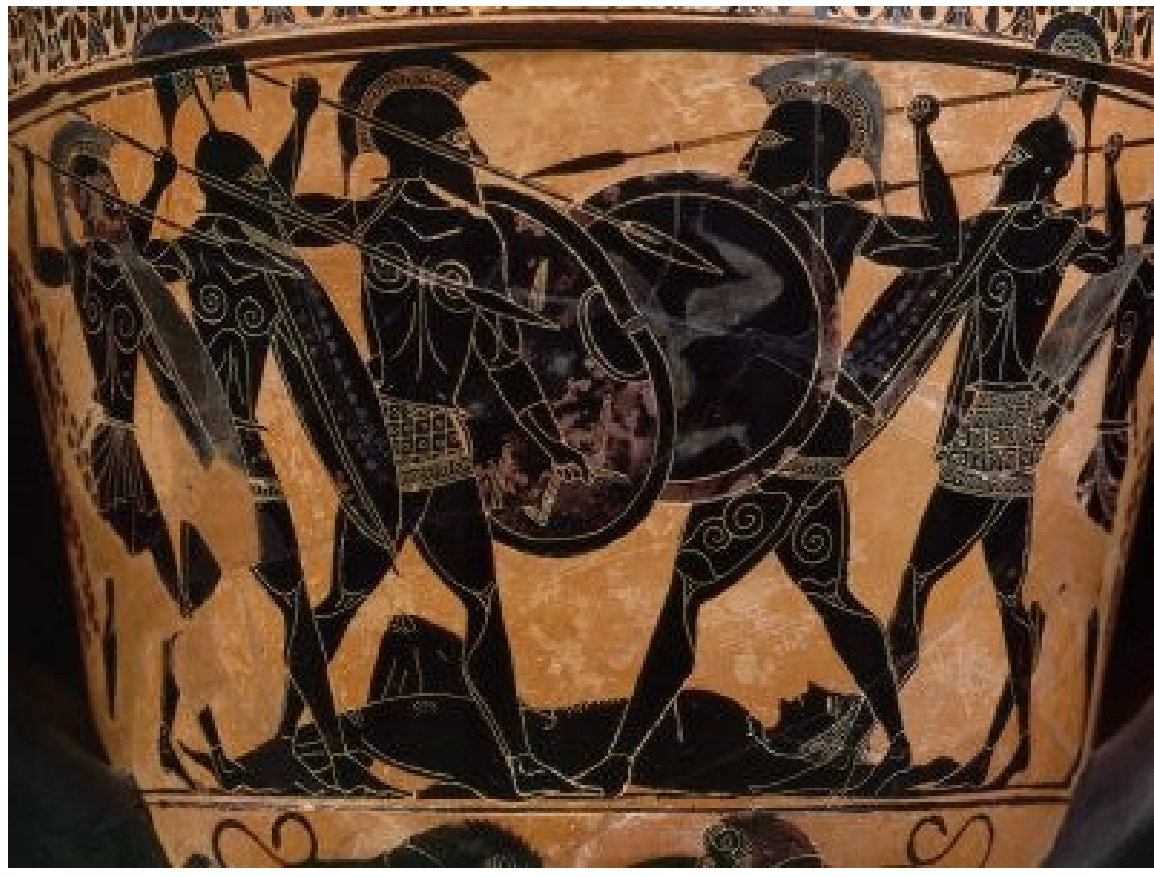

Görsel 10. Akhilleus’un Patroklus’u savaş alanından almak için mücadelesi

\subsubsection{Akhilleus ve Hektor'un destansı çarpış̧ması}

İlyada Destanının en önemli sahnesi kuşkusuz ki, Akhaların kahramanı Akhilleus ile Troyalıların kahramanı Hektor arasındaki birebir ve ölümüne yaptıkları çarpışmadır. Öylesi bir kapışmadır ki, sanki yenilen sadece hayatını kaybetmekle kalmayacak, aynı zamanda savaşı da kaybedecektir. Bu iki kahramanın göğüs göğüse çarpışması en destansı şekilde ustaca anlatılmıştır. Ancak kaybedenin kim olacağına yine tanrılar karar vereceklerdir. Zeus kader tartısını kaldırır ve Hektor'un ölüm kefesi daha ağır basar. Hektor tanrıların kendisini terkettiğini anlarcasına, Akhillus'tan yenilen savaşçı için cenaze ritüellerine uygun davranılmasını, yani bir centilmenlik anlaşması yapılmasını ister ancak gözünü intikam ve hırs bürümüss olan Akhilleus bunu reddetmektedir. Uzunca bir savaştan sonra, Akhilleus mızrağını Hektor'un en korumasız yerine saplayarak onu öldürdüğü ifade edilmektedir (Aslan, 2018, s. 15-16).

Bu efsane dizeleri Homeros'in kendi anlatımından ve Erhat'ın şiirsel çeviri üslubuyla aynen aktaracak olursak:

"Akhilleus da saldırdı, yüreği azgın bir güçle dolu,

Göğsünü güzel, işli kalkanıyla kapadı,

Parlak, dört siperli tolgası vardı başında,

Güzelim altın yeleler s1k sık dökülüyordu,

Hephaistus'un taktığı sorguçtan aşağı.

...

Sağ elinde sallanan sipsivri kargi öyle parlıyordu.

Akhilleus bu kargıyla kötülük kuruyordu Hektor'a,

Hesapliyordu güzel etinin en iyi neresine gireceğini.

Bütün gövdesi kaplıydı tunç silahlarla,

Zorla öldürdüğü Patroklos'u

Ondan soyduğu güzel silahlardı bunlar. 
Bir tek yeri açık kalmıştı Hektor’un,

Köprücük kemiğinin omzu boyundan ayırdığı yer,

Adamın çok kolay canı alınırdı ordan.

Ateşli bir saldırışla sapladı kargıyı oraya.

Temren dosdoğru girdi yumuşak boğazdan içeri.” (XXII. Bölüm, Dize: 313-327)

Bu unutulmaz sahne, İngiltere'de British Museum'da sergilenmekte olan kırmızı figürlü, M.Ö. 490'a tarihlenen bir şarap vazosunda işlenmiştir. Vazoda, Akhilleus'a Athena, Hektor'a Apollo'nun destek verdiği görülmektedir (bkz. Görsel 11).

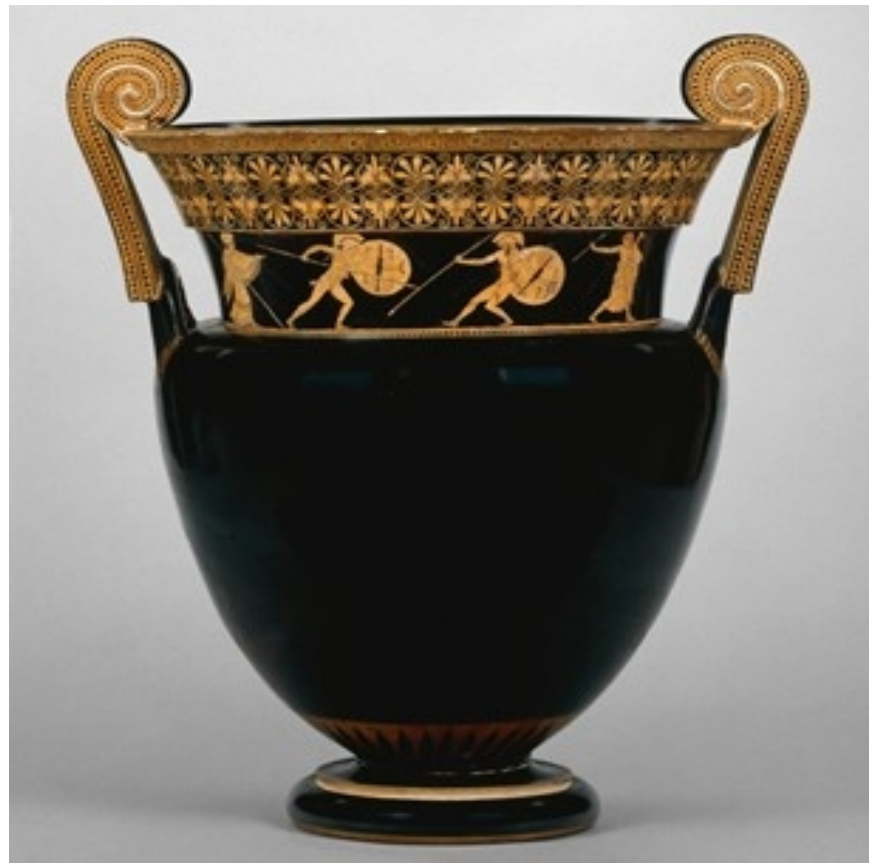

Görsel 11. Akhilleus ve Hektor’un çarpışması. (M.Ö.490). Kırmızı Figürlü Vazo, British Museum, İngiltere

\subsubsection{Hektor'un bedenine işkence}

Destanda Hektor artık ölmüştür ancak hırsı geçmeyen Akhilleus, Hektor'un hakettiği ritüellere uygun bir cenaze töreni yapılmasına dahi izin vermektedir. Hector'un cansız bedenini atlı arabasının arkasına bağlar ve güvenli bir mesafeden günlerce Troya surları etrafinda sürükleyerek onu paramparça etmektedir. Bu yürek parçalayııı sahneyi, babası Kral Priamos, annesi Hekabe, kardeşi Paris ve karısı Andromache'nin surlardan çaresizce izlediği tasvir edilmektedir. Homeros XXII. Bölüm, Dize: 395-404'de bu anları şu şekilde anlatmaktadır:

“(Achilleus) Hektor için düşündü kötü şeyler,

İki ayağını bilekle topuk arasından deldi,

Kayışlar geçirdi deliklerden, bağladı arabaya,

Başı bıraktı yerde sürüklensin diye,

Sonra atladı arabaya ünlü silahlarıyla.

Kamçıladı atları, atlar öne atılıp coştu

Yerde sürüklenen gövdenin çevresinde

Bir toz bulutu yükseldi birdenbire.

Toz toprak içinde kaldı bütün başı,

Kopkoyu saçları darmadağın oldu.” (Homeros, 2002, s. 481).

Boston, Amerika'da, Museum of Fine Arts'ta bulunan ve M.Ö. 520'ye tarihlenen siyah figürlü bir hydria da (Su kabı) (bkz: Görsel 12), Akhilleus'un Hector’un cansız bedenini iki atın çektiği arabasının arkasına bağlayıp, sürüklemesi resmedildiği görülmektedir. Temsilde, en solda Hektor'un karısı Andromache kocası için yas tutmaktadır. Yanında yuvarlak kalkanıyla Akhilleus, Hermes ve İris vardır. En sağda ise, Patroklus'un mezarı ve daha küçük resmedilen kalkanlı savaşcı ise Patroklus'tur. Sanatçı birkaç farklı sahneyi aynı kompozisyonda anlatmaktadir. 


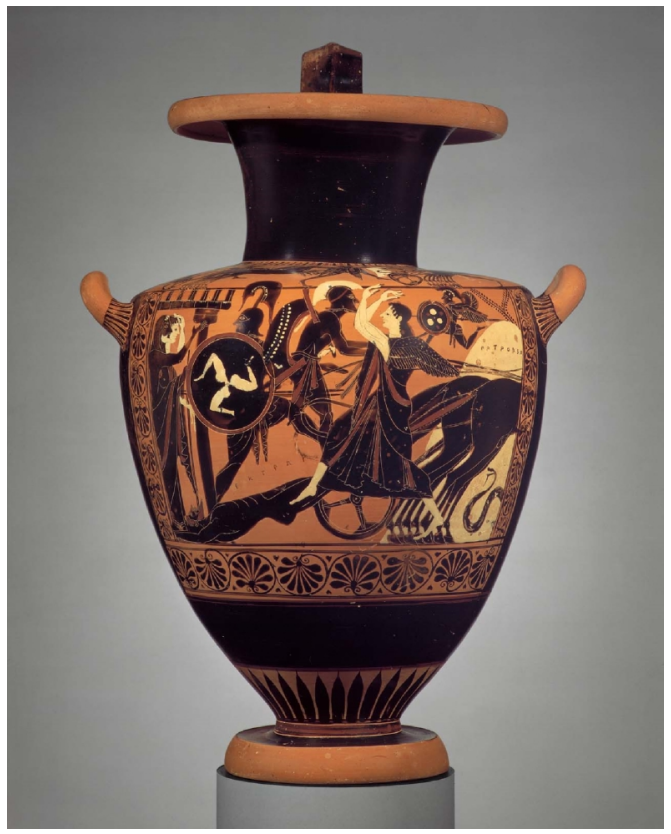

Görsel 12. Siyah Figürlü Hydria, (M.Ö. 520). Museum of Fine Arts Boston, Amerika

\subsubsection{Priamos'un Hektor'un cansız bedenini Akhilleus'tan istemesi}

Destana göre Akhilleus'un Hektor'un bedenini Troya surları etrafinda günlerce sürüklemesine Tanrılar daha fazla dayanamazlar. Hektor'un geleneklere uygun bir cenaze törenini hakettiği düşünülmektedir. Tanrıların habercisi İris'i Kral Priamos'a gönderirler, İris ona Akhilleus'a gitmesini ve oğlunu istemesini iletir. Homeros'un XXIV. Bölüm, Dize: 143-156 ve XXIV. Bölüm, Dize: 499-506'daki anlatımına göz atacak olursak:

"Kronosoğlu (Zeus) gönderdi İrisi kutsal İlyona.

Durma, hızlı İris, çık yola, in Olympos’tan aşağı,

Ulu Yürekli Priamos'a İlyonda ilet şu haberi:

Gitsin Akhalar'ın gemilerine, geri alsın oğlunu,

Armağanlar götürsün, hoş etsin gönlünü Akhilleus'un.

Gitsin tek başına, almasın yanına bir başka adam.

Sonra da alıp getirir kente,

Tanrısal Akhilleus'un öldürdüğ̈̈ Hektor'u.

Girmesin yüreğine ölüm korkusu ya da bir başka kayg1,

Hermes'i kılavuz vereceğiz ona,

Götürecek onu Akhilleus'un yanına dek.

Priamos barakanın içine girdiğinde,

Onu ne Akhilleus ne de başkası öldürecek.”

Yaşlı Priamos dalıverdi içeri,

Zeus'un sevdiği Achiileus'u buldu içeride.

Gitti durdu Akhilleus'un yanında,

Sarıldı dizlerine, öptü ellerini, Nice oğullarının almıştı canını,

O korkunç eller, o kanlı eller.

Biri gözümün bebeğiydi, korurdu kentimi, halkımı,

Yurdunu savunurken geçen gün sen öldürdün onu da,

Onun için geldim Akha gemilerine, Hektor için,

Değer biçilmez kurtulmalıklar getirdim sana.

Saygı göster tanrılara Akhilleus, bana da acı,

Ne olur, kendi babanı getir aklına,

Ben daha acınacak durumdayım ondan,

Yeryüzünde hiçbir ölümlü katlanmadı benim katlandığıma:

Oğlumu öldürenin ağzına uzatıyorum yalvaran elimi (Homeros, 2002, s. 516-526). 
Priamos ile Akhilleus arasındaki konuşmadan sonra Akhilleus; Hektor'un cansız bedenini babasına teslim etmekte ve cenaze törenleri için savaşa on gün ara vermektedir. Priamos, Hektor'un ölüsünü Troya'ya götürmekte, karısı Andromache ve annesi Hekabe de büyük üzüntü içindedir.

Viyana, Avusturya'da, Kunst Historisches Museum'da bulunan ve M.Ö. 490’a tarihlenen kırmızı figür tekniği ile yapılan bir skypost ta (iki kulplu derin şarap kabı), Kral Priamos'un Akhilleus'a yalvarması konusunun işlendiği görülmektedir. Priamos maiyeti ile birliktedir, Akhilleus'a ise hizmetçisi eşlik etmektedir. Hektor'un bedeni yerde boylu boyunca uzanmaktadır. Duvarda ise Akhilleus'un miğferi ve kalkanı asılı olarak tasvir edilmiştir (bkz: Görsel 13).

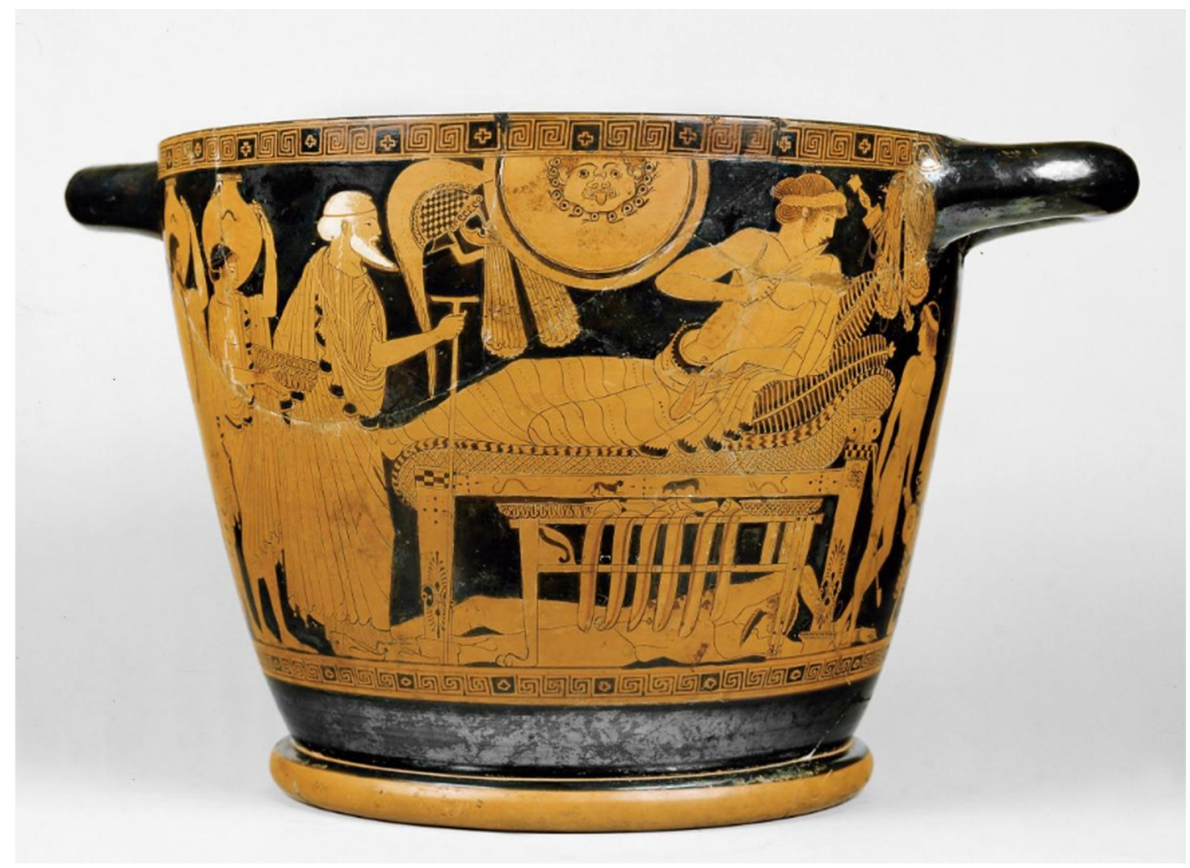

Görsel 13. Kral Priamos'un Akhilleus'a yalvarmas1. (M.Ö.490). Skypost, Kunsthistorisches Museum, Viyana

\subsubsection{Troya atı ve kentin düşüşü}

Homeros, İlyada'yı Hektor'un cenaze merasimlerinden sonra bitirmektedir. Ancak, tabiki de bu savaş henüz bitmemiştir. Azra Erhat'a göre Troya Savaşı'nın bütün mazisini “kyklos” diye adlandırılan bir destanlar çemberi sayesinde bilmekteyiz ve bilgilerin çoğunu da Hellenistik çağlardan kalma derleyicilerin yapıtlarına borçluyuz (Homeros, 2002, s. 30).

Hektor'u öldüren Akhilleus kendisinin de çok fazla yaşamayacağını bilmektedir. Homeros Akhilleus'un kötü kaderini XXII. Bölüm, Dize: 356-360'da okuyucuya bildirmektedir. Annesi Thetis de bunu kendisine savaştan önce söylemiştir. Hektor ölmek üzereyken Akhilleus'a şöyle seslenir:

"Senin ne olduğun yüzünden belli,

Demirden bir yürek var göğsünde.

Ama uyanık ol, uğramayasın tanrı lanetine,

Yiğit de olsan, Paris ile Apollon, o gün seni,

Öldürecekler batı kapılarının önünde.” (Homeros, 2002, s. 480)

Destana göre Akhilleus'un ölümü kahramanca bir çatışma ile olmamıştır. Tam da Hektor'un dediği gibi, Paris'in attığg ok, Apollon'un da yönlendirmesiyle onu en zayıf noktası olan topuğundan vurmaktadır. Topuğundan vurulan Akhilleus orada ölür ve böylece Apollon da kutsal alanına zarar veren Akhilleus'tan intikamını almış olur (Aslan, 2018, s. 16-17).

Artık savaş sona yaklaşmıştır. Hem Hektor, hem de Akhilleus ölmüştür. Silahların veya kahramanların gücüyle değil, sinsi bir plan ve hile ile bitecektir savaş. Akhalar, savaştan vazgeçip geri döndükleri izlenimi vermek için tüm gemilerini yakındaki bir koya gizlemişlerdir. İthaka Kralı Odysseus'un emriyle tahtadan bir at heykelini Troya surlarının önüne bırakırlar. Troyalılar tahta atı tanrılara adanmış bir kutsal hediye zannedip, surların içine getirmişlerdir. Atın içine Akha askerleri gizlenmiştir. Geceleyin dışarı çıkan askerler kentin kapılarını açarlar ve böylece Troya fethedilir. Akhalılar Troya'yı yakıp, yıkarlar ve kent yerle bir edilmiştir (Graves, 2012, s. 906-912). 


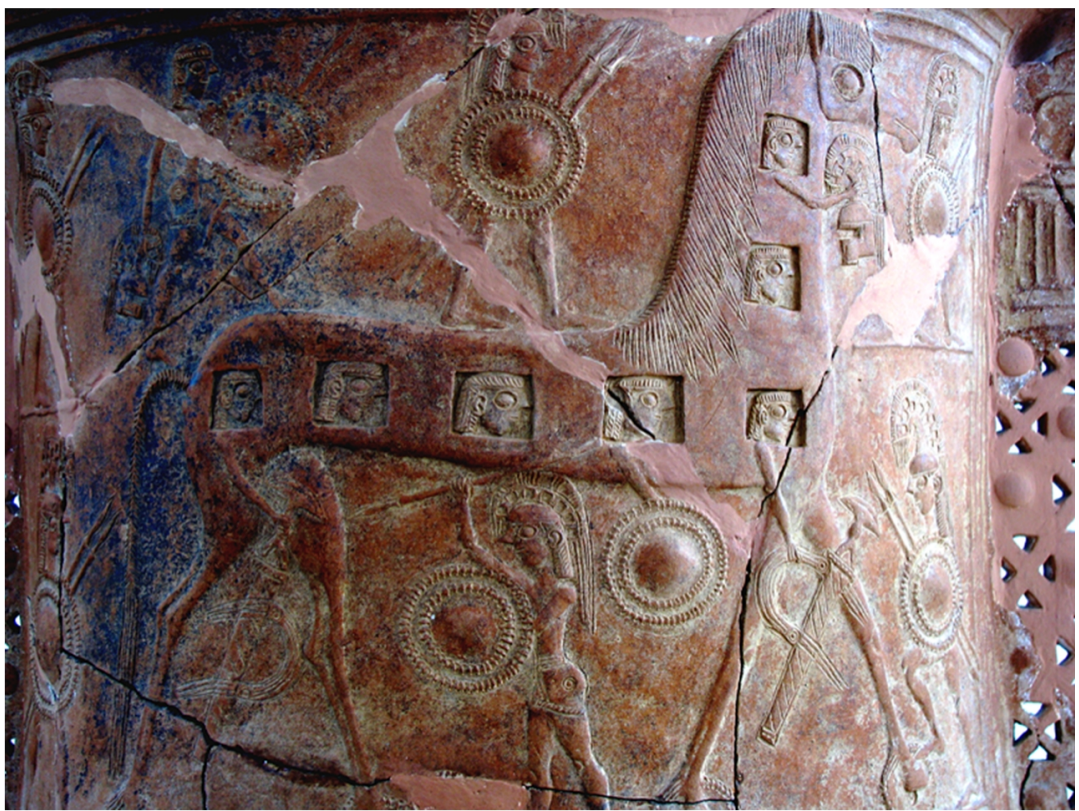

Görsel 14. Mikonos Vazosu. (M.Ö.670)

Yunanistan'da, Mikonos Arkeoloji Müzesi’nde sergilenmekte olan “Mikonos Vazosu” (bkz. Görsel 14), Troya atı sahnesinin betimlendiği bilinen en eski eserdir. M.Ö. 670 yılına tarihlenen bu vazonun en önemli özelliği Truva Atı'nın bilinen en erken betimlemesinin bu vazo üzerinde yer alması olup, vazo 1961 yılında Mikonos adasında bulunmuştur. Siyah figürlü seramiklerin kullanımına başlanmasından bir yüzyıl öncesine tarihlenen bu seramik vazoda içi Akhalı askerlerle dolu attan çıkıp, Troya’yı fetheden askerler resmedilmiştir.

\section{Sonuç}

Homeros'un destanı İlyada, antik çağlardan beri sanatın ve edebiyatın değişmez temaları arasında yer almıştır. On yıl boyunca acımasızca birbirleriyle savaşan Akhalar ve Troyalılar sanatçılara ilham kaynağı olmuştur. Öfkeli ve intikamcı Akhilleus, yurtsever Hektor, en güzel ölümlü Helen, Paris, Kral Priam, Patroklus, Aias, Andromache ve daha birçok kahraman bu eserler sayesinde günümüze kadar gelmişlerdir.

Seramik, insanlar tarafından kullanılmaya başlandığg tarihten itibaren sadece günlük yaşamda ihtiyaç duyulan objeleri üretmek için kullanılan bir malzeme olmamış; aynı zamanda seramik formlar üzerinde yeni teknikler geliştirilerek sanatsal faaliyetler için yeni bir alan açmıştır. Önceleri kullanım amaçlı üretilen seramik eşyaların zamanla form ve süsleme bakımından geliştirildiği görülmektedir. Estetik açıdan gelişip yaygınlaşan bu seramik objeler Antik Yunan döneminde önemli bir yere sahip olmuştur. Özellikle resimsel betimlemelere ve süslemelere oldukça önem verilen bu dönemde dini ve mitolojik sahnelerin seramik yüzeylerde tasviri ile tinsel amaçlı da kullanıldıkları seramik objeler sayesinde, kendine farklı bir malzeme bulmuş olan resim sanatını icra eden ustaların ve sanatçıların vazo ressamlığı sayesinde, yaşadıkları dönemin özelliklerini, konularını, inançlarını, korkularını günümüze kadar taşıyarak geçmişe dair bilgiyi aktaran eserler olduklarını görmekteyiz.

Antik dönem kırmızı ve siyah figürlü seramik eserleri, Troya'nın efsane olaylarını ve unutulmaz kahramanlarını seramikten yapılmış vazo, çömlek ve benzeri kapların üzerinde betimlenen tasvirler sayesinde tarihe tanıklık ederek günümüze kadar gelebilmesi ve bu sayede de kültürel mirasın sonraki nesillere aktarılmasında önemli görevler üstlendiği görülmektedir. Gündelik kullanım için yapılan basit seramik obje ve kapların aksine, seramik ustaları ve vazo ressamları sayesinde figürlerle bezenen seramikler, kısıtlı bir alanda sahneleri başarılı bir şekilde anlatmış ve nitelikli sanat eserleri olarak dünya seramik mirasında yerini almış olduğu görülmektedir.

Geçmişten günümüze gelen bir belge niteliğindeki seramik kaplar, yazılı bir metnin kavranmasında araç olurken, dönemin adetleri ve gelenekleri hakkında da insanlık tarihine kaynak olmaktadır. Aynı zamanda Antik dönemden günümüze kadar ulaşan bu eserler sayesinde, gündelik kullanım eşyası dışındaki önemli ve özel günlerde kullanılan ritüel ve kült seramik kapları sayesinde, iki renkli astarın kullanımını ve geçmişte seramik sanatı teknolojisinin gelişimini izleme imkanının yanı sıra, üretim aşamasında kullanılan firça, pergel, kompas, vb. malzeme, alet ve üretim tekniği hakkında önemli veriler elde edilmektedir.

\section{Kaynakça}

Aslan, E. E.; \& Canduran, K. (Ed.). (2016). Seramik pişirim teknikleri ve fırınları. Ankara: Opus Basımevi.

Aslan, R. (2018). Arkeolojinin destanı: Troia, 300. sayı. İstanbul: Atlas Yayınlar1. 
Çizer, S. (2014). Terra sigillata. İzmir: Tibyan Yayıncılık.

Dphil, A. A. (2011). The early black-figured pottery of Attika in context. Boston: Leiden.

Graves, R (2012). Yunan mitleri: tanrlar, kahramanlar, söylenceler. İstanbul: Say Yayınları.

Homeros. (2001). Odysseia (12. Basım). (A. Erhat ve A. Kadir, Çev.). İstanbul: Can Yayınları.

Homeros. (2002). İlyada. (13. Basım). (A. Erhat ve A. Kadir, Çev.). İstanbul: Can Yayınları.

Khan Academy. (t.y.). Ancient Greek vase production and the black-figure technique. Erişim adresi: https://www.khanacademy.org/humanities/ancient-art-civilizations/greek-art/greek-pottery/v/ancient-greekvase-black-figure-technique

Kültür Varlıkları ve Müzeler Genel Müdürlüğü. (t.y.). Dünya miras listesi. Erişim adresi: http://www.kulturvarliklari.gov.tr/TR,44423/dunya-miras-listesi.html.

Kültür Varlıkları ve Müzeler Genel Müdürlüğü. (t.y.). Troya antik kenti (Çanakkale). Erişim adresi: http://www.kulturvarliklari.gov.tr/TR,44431/troya-antik-kenti-canakkale.html

Önal, N. O., \& Uludağ, K. (2019). Sanayi devrimi öncesi seramik sanatı tarihi. Ankara: Gece Akademi.

Yoleri, H. (2008). Pişmiş kil ile iletişim: seramik üzerine yazılar. İzmir: Tibyan Yayıncılık.

\section{Görsel Kaynakçası}

Görsel 1. Antik Dönem Yunan kaplarının tipolojisi. Kaynak: Çizer, S. (2014). Terra Sigillata. İzmir: Tibyan Yayınc1lik

Görsel 2. Seramik formun astarlanması. (2019). Erişim adresi: https://www.khanacademy.org/humanities/ancientart-civilizations/greek-art/greek-pottery/v/ancient-greek-vase-black-figure-technique

Görsel 3. Astarlanmış seramik formun üzerine çizimin yapılması. (2019). Erişim adresi: https://www. khanacademy.org/humanities/ancient-art-civilizations/greek-art/greek-pottery/v/ancient-greek-vase-blackfigure-technique

Görsel 4. Çizimlerin içlerinin astarlanması. (2019). Erişim adresi: https:/www.khanacademy.org/humanities/ ancient-art-civilizations/greek-art/greek-pottery/v/ancient-greek-vase-black-figure-technique

Görsel 5. Seramiklerin pişirildiği fırın. (2019). Erişim adresi: https://www.khanacademy.org/humanities/ancientart-civilizations/greek-art/greek-pottery/v/ancient-greek-vase-black-figure-technique

Görsel 6. Pişirim esnasından bir görünüm. (2019). Erişim adresi: https://www.khanacademy.org/humanities/ ancient-art-civilizations/greek-art/greek-pottery/v/ancient-greek-vase-black-figure-technique

Görsel 7. Pişirim sonrasından bir görünüm. (2019). Erişim adresi: https://www.khanacademy.org/humanities/ ancient-art-civilizations/greek-art/greek-pottery/v/ancient-greek-vase-black-figure-technique

Görsel 8. Paris'in Kararı. (M.Ö. 7.yy.). Staatliche Museen zu Berlin'de Bir Vazo. [Seramik]. Erişim adresi: https://www.researchgate.net/figure/The-judgement-of-Paris-Detail-from-a-ceramic-cup-Paris-sitting-in-theright-Hermes_fig3_258129939

Görsel 9. Paris'in Kararı. (MÖ 6. yy.). Siyah Figürlü Boyama Tekniği. Lyon Güzel Sanatlar Müzesi. [Seramik]. Erişim adresi: https://www.marcmaison.fr/architectural-antiques-resources/jugement_de_paris

Görsel 10. Akhilleus'un Patroklus'u savaş alanından almak için mücadelesi. (2018). [Seramik]. Kaynak: Aslan, R. (2018). Arkeolojinin destanı: Troia, 300. sayı. İstanbul: Atlas Yayınları.

Görsel 11. Akhilleus ve Hektor'un çarpışması. (M.Ö.490). Kırmızı Figürlü Vazo, British Museum, İngiltere. [Seramik]. Erişim adresi: http://www.britishmuseum.org/research/collection_online/collection_object_details. aspx?objectId=461901\&partId=1\&images $=$ true

Görsel 12. Siyah Figürlü Hydria, (M.Ö.520). Museum of Fine Arts Boston, Amerika. [Seramik]. Erişim adresi: https://collections.mfa.org/objects/

Görsel 13. Kral Priamos’un Akhilleus'a yalvarması. (M.Ö.490). [Seramik]. Skypost, Kunst Historisches Museum, Viyana. Erişim adresi: https://www.khm.at/objektdb/detail/56696/

Görsel 14. Mikonos Vazosu. (M.Ö. 670). [Seramik]. Erişim adresi: https://commons.wikimedia.org/wiki/File: Mykonos_vase_7th_cent_bce_early_depiction_of_Trojan_Horse_photographed_by_Travellingrunes_Flickr_ 2949254926_4c9dc0882d_o.png 